\title{
Synthesis of oxo analogs of Lamotrigine and related compounds ${ }^{1}$
}

\author{
Jan Hlaváč, Roman Buchtík, Jan Slouka, Pavel Hradil, and Iveta Wiedermannová \\ Department of Organic Chemistry, Palacký University, Tr. Svobody 8, CZ-771 46 Olomouc, \\ Czech Republic. \\ E-mail: hlavac@prfnw.upol.cz
}

(received 15 Sep 02; accepted 24 Mar 03; published on the web 09 Apr 03)

\begin{abstract}
Lamotrigine oxoanalog 8 was prepared using 5-(2-amino-5,6-dichlorophenyl)-6-azauracil 3 as starting compound. A series of 5-(2,3-dichlorophenyl)-6-azauracil derivatives 9-12 with additional substituents in the benzene ring were synthesized as well. The conversion of hydrazone 13 to derivative 14 containing two 6-azauracil rings is also described.
\end{abstract}

Keywords: Lamotrigine analogs, 6-azauracils, isatin semicarbazone recyclization

\section{Introduction}

In the search of new biologically active compounds a common method is the structural modification of compounds with well established activity. ${ }^{2}$ With respect to the anticonvulsant Lamotrigine, i.e. 3,5-diamino-6-(2,3-dichlorophenyl)-[1,2,4]triazine, ${ }^{3,4}$ only analogs with varied substituents in the benzene ring have been prepared up to now. ${ }^{5}$ In continuation of our studies on heterocyclic N-H acids with potential biological activity, ${ }^{6-8}$ we focus in this communication on analogs of Lamotrigine with modifications of the heterocyclic moiety.

\section{Results and Discussion}

For the synthesis of the Lamotrigine analog 8 and its halogenated derivatives, 5-(2-amino-5,6dichlorophenyl)-6-azauracil $\mathbf{3}$ served as key intermediate; it was prepared by a two step synthesis starting from 4,5-dichloroisatin 1 (Scheme 1): Condensation with semicarbazide hydrochloride yielded the semicarbazone $\mathbf{2}$; boiling of $\mathbf{2}$ in aqueous sodium hydroxide solution afforded the $[1,2,4]$ triazine-3,5-dione derivative 3 . During the alkali-induced cyclization process the semicarbazone 2 was also hydrolysed to 4,5-dichloro-1H-indole-2,3-dione 3-hydrazone (4), which in turn, underwent immediate Wolff-Kishner reduction affording 4,5-dichloro-1,3-dihydro- $2 \mathrm{H}$ indol-2-one (5). The course of this reaction was proved by an independed synthesis of indol-2- 
one 5 employing hydrazone 4, which was easily obtained by condensation of 4,5-dichloroisatin (1) with hydrazine. Heating of compound $\mathbf{3}$ in acetic acid brought about cyclocondensation to 8,9-dichloro-2,5-dihydro-3H-[1,2,4]triazino[5,6-b]indol-3-one (6). Attempts to convert the semicarbazone 2 into derivative 6 by thermal or acetic acid-induced cyclization failed.

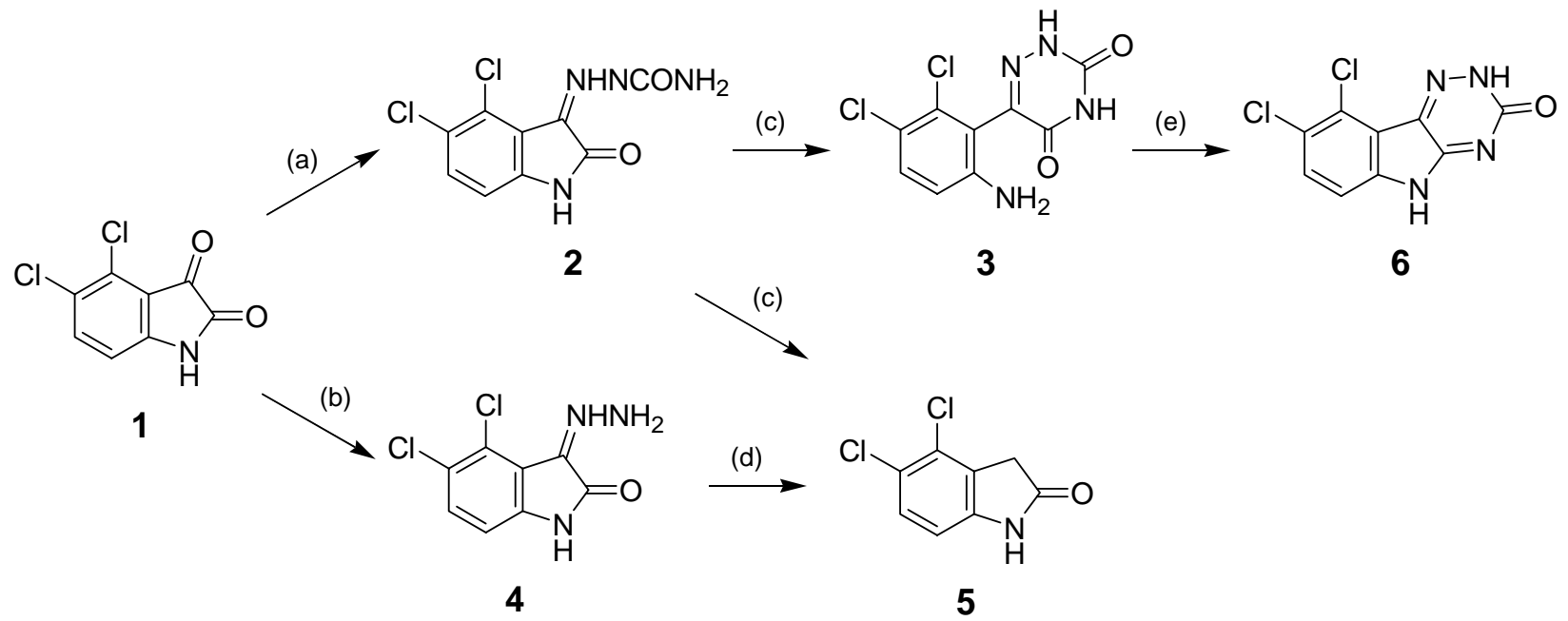

Scheme 1. (a) $\mathrm{H}_{2} \mathrm{NNHCONH}_{2} \bullet \mathrm{HCl}, \mathrm{AcOH}$, reflux; (b) $\mathrm{H}_{2} \mathrm{NNH}_{2} \bullet \mathrm{H}_{2} \mathrm{O}, \mathrm{AcOH}$, reflux; (c) (1) $\mathrm{NaOH}$, reflux; (2) $\mathrm{AcOH}$; (d) (1) $\mathrm{NaOH}$; (2) $\mathrm{HCl}$; (e) $\mathrm{AcOH}$, reflux.

Triazine 3 was diazotated in hydrochloric or sulfuric acid without any problem. The resultant diazonium salt 7 when treated with hypophosphorous acid eliminated dinitrogen and led to 5(2,3-dichlorophenyl)-6-azauracil (8).

Sandmeyer reaction of the diazonium salt 7 with cuprous chloride or cuprous bromide afforded 5-(2,3,6-trichlorophenyl)-6-azauracil (9) and 5-(2-bromo-5,6-dichlorophenyl)-6-azauracil (10), respectively (Scheme 2). The diazonium salt 7, when treated with potassium iodide, gave 5-(5,6-dichlorophenyl-2-iodo)-6-azauracil (11). Diazotation in sulfuric acid solution with subsequent boiling yielded 5-(2,3-dichloro-6-hydroxyphenyl)-6-azauracil (12).

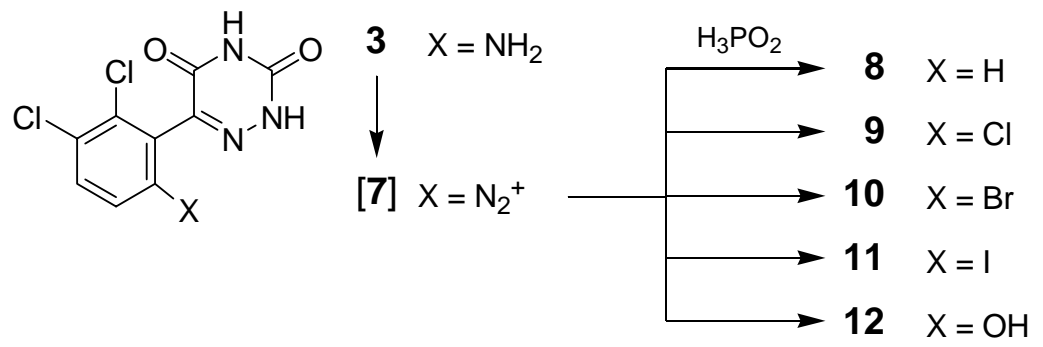

\section{Scheme 2}


The coupling reaction of diazonium salt 7 with ethyl cyanoacetylcarbamate afforded ethyl 2cyano-2-[[3,4-dichloro-2-(3,5-dioxo-2,3,4,5-tetrahydro[1,2,4]triazin-6-yl)phenyl]hydrazono]ethanoylcarbamate (13). Upon boiling in pyridine 13 underwent cyclization to 2-[3,4-dichloro-2(3,5-dioxo-2,3,4,5-tetrahydro[1,2,4]triazin-6-yl)phenyl]-3,5-dioxo-2,3,4,5-

tetrahydro[1,2,4]triazine-6-carbonitrile (14) (Scheme 3); this compound is interesting in view of possible interactions involving intermolecular hydrogen bonds with substrates containing two bonding centers.

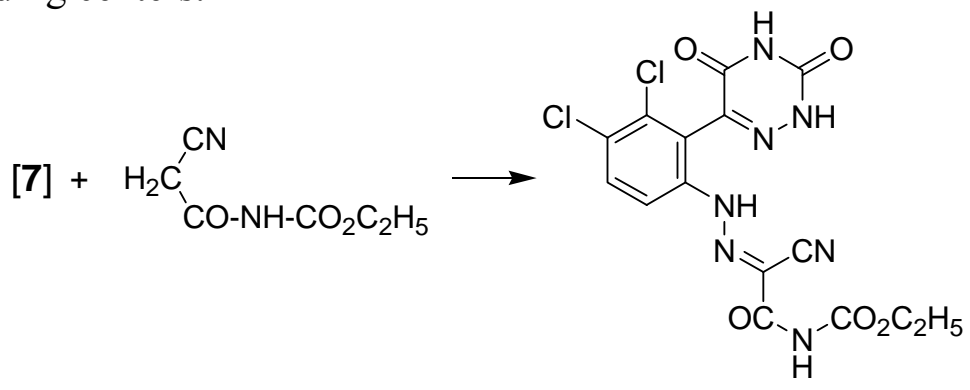

13

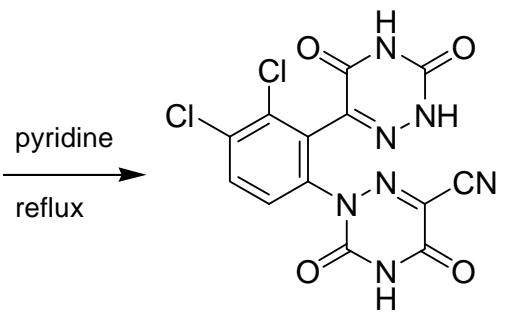

14

\section{Scheme 3}

In summary, the 6-azauracil derivatives 8-12 could be interesting from the viewpoint of biological activity, e.g. exhibiting anticoccidial ${ }^{9,10}$ or herbicidal activity. ${ }^{11}$

\section{Experimental Section}

General Prcedures. Melting points were determined on a Boetius stage. Infrared spectra $(\mathrm{KBr}$ disks) were taken with an ATI Unicam Genesis FTIR instrument. NMR spectra of solutions in DMSO- $d_{6}$ (TMS as internal standard) were measured on Avance 300 (Bruker $300 \mathrm{MHz}$ ). Mass spectrometric experiments were performed using an LCQ ion trap mass spectrometer (Thermo Finnigan, San Jose, CA) equipped with electrospray ionization. Mass spectra were measured in the negative ion mode (spray voltage $-5.0 \mathrm{kV}$ ). The sample solutions (approximately $10 \mu \mathrm{g} / \mathrm{mL}$ methanol) were directly introduced into the ion source with a flow rate of $5 \mu \mathrm{L} / \mathrm{min}$. Elemental analyses were obtained with an EA 1108 Elemental Analyzer (Fison Instrument).

4,5-Dichloro-1H-indole-2,3-dione 3-semicarbazone (2). 4,5-Dichloroisatin (1) ${ }^{12}(1.00 \mathrm{~g}, 5$ mmol) was dissolved in boiling acetic acid $(50 \mathrm{~mL})$, and a solution of semicarbazide hydrochloride $(0.60 \mathrm{~g}, 5 \mathrm{mmol})$ in water $(10 \mathrm{~mL})$ was added. The mixture was stirred and boiled for $10 \mathrm{~min}$. After cooling the solid formed was filtered off, washed with acetic acid followed with water. The dried, product was recrystallized from acetic acid affording yellow crystals 2 (0.95 g, $75 \%$ ); mp 318-323 ${ }^{\circ} \mathrm{C}$ (ethanol). IR (KBr): $\widetilde{v} 3466(\mathrm{NH}), 3288(\mathrm{NH}), 1715 \mathrm{~cm}^{-1}$ $(\mathrm{C}=\mathrm{O}) ;{ }^{1} \mathrm{H}$ NMR $\left(300 \mathrm{MHz}, \mathrm{DMSO}-d_{6}\right): \delta 6.95\left(1 \mathrm{H}, \mathrm{d}, J=7 \mathrm{~Hz}, \mathrm{H}_{\text {arom }}, 7.18\left(2 \mathrm{H}, \mathrm{s}, \mathrm{NH}_{2}\right), 7.57\right.$ 
$\left(1 \mathrm{H}, \mathrm{d}, J=7 \mathrm{~Hz}, \mathrm{H}_{\text {arom }}\right), 11.49(1 \mathrm{H}, \mathrm{s}, \mathrm{NH}), 12.09$ (1H, s, NH). MS: m/z $271\left(\mathrm{M}-\mathrm{H}^{+}\right)$. Anal. Calcd. for $\mathrm{C}_{9} \mathrm{H}_{6} \mathrm{Cl}_{2} \mathrm{~N}_{4} \mathrm{O}_{2}$ (273.08): C, 39.59 , H, 2.21; N, 20.52. Found: C, 39.76; H, 1.77; N, 20.09 .

6-(6-Amino-2,3-dichlorophenyl)[1,2,4]triazine-3,5(2H,4H)-dione (3). Semicarbazone 2 (2.00 $\mathrm{g}, 7.3 \mathrm{mmol})$ was dissolved in a boiling solution of sodium hydroxide $(1 \mathrm{M}, 100 \mathrm{~mL})$ This mixture was boiled for $3 \mathrm{~h}$ and after cooling was acidified with acetic acid. The resulting solid was immediately filtered off, washed with water and dried affording the yellow solid $\mathbf{3}$ (1.19 $\mathrm{g}$, 59\%); mp above $360{ }^{\circ} \mathrm{C}$ (ethanol). IR (KBr): $\widetilde{v} 3407(\mathrm{NH}), 3055\left(\mathrm{C}-\mathrm{H}_{\text {arom}}\right), 1746 \mathrm{~cm}^{-1}(\mathrm{CO}) ;{ }^{1} \mathrm{H}$ NMR (300 MHz, DMSO- $\left.d_{6}\right): \delta 5.69\left(2 \mathrm{H}, \mathrm{s}, \mathrm{NH}_{2}\right), 6.67\left(1 \mathrm{H}, \mathrm{d}, J=7 \mathrm{~Hz}, \mathrm{H}_{\text {arom }}\right), 7.32(1 \mathrm{H}, \mathrm{d}, J=$ $\left.7 \mathrm{~Hz}, \mathrm{H}_{\text {arom }}\right), 12.11(1 \mathrm{H}, \mathrm{s}, \mathrm{NH}), 12.49(1 \mathrm{H}, \mathrm{s}, \mathrm{NH})$. Anal. calcd. for $\mathrm{C}_{9} \mathrm{H}_{6} \mathrm{Cl}_{2} \mathrm{~N}_{4} \mathrm{O}_{2}$ (273.08): C, 39.59; H, 2.21; N, 20.52. Found: C, 39.72; H, 1.97; N, 20.22.

4,5-Dichloro-1H-indole-2,3-dione 3-hydrazone (4). 4,5-Dichloroisatin ${ }^{12}(0.10 \mathrm{~g}, 0.5 \mathrm{mmol})$ was dissolved in boiling acetic acid $(5 \mathrm{~mL})$. To this solution was added hydrazine hydrate $(80 \%$, $0.5 \mathrm{~mL}, 10 \mathrm{mmol})$. The precipitated solid was filtered off, washed with acetic acid and water and then dried to give the yellow solid 4 (0.95 g, 90\%); mp 270-271 ${ }^{\circ} \mathrm{C}$ (ethanol). IR (KBr): $\widetilde{v} 3389$ $(\mathrm{NH}), 3226(\mathrm{NH}), 1693 \mathrm{~cm}^{-1}(\mathrm{CO}) ;{ }^{1} \mathrm{H}$ NMR (300 MHz, DMSO-d $): \delta 6,85(1 \mathrm{H}, \mathrm{d}, J=8 \mathrm{~Hz}$, $\left.\mathrm{H}_{\text {arom }}\right), 7.36\left(1 \mathrm{H}, \mathrm{d}, J=8 \mathrm{~Hz}, \mathrm{H}_{\text {arom }}\right), 10.10\left(1 \mathrm{H}, \mathrm{d}, J=15 \mathrm{~Hz}, \mathrm{NH}_{2}\right), 11.03$ (1H, br s, NH). Anal. calcd. for $\mathrm{C}_{8} \mathrm{H}_{5} \mathrm{Cl}_{2} \mathrm{~N}_{3} \mathrm{O}$ (230.05): C, 41.77; H, 2.19; N, 18.27. Found: C, 41.21; H, 1.64; N, 17.87. 4,5-Dichloro-1,3-dihydro-2H-indol-2-one (5).

Method 1. Hydrazone $4(0.50 \mathrm{~g}, 2 \mathrm{mmol})$ was dissolved in a solution of sodium hydroxide $(10 \%$, $50 \mathrm{~mL}$ ). The mixture was boiled for $1 \mathrm{~h}$. After cooling the mixture was acidified with hydrochloric acid to $\mathrm{pH} 2$. The pink solid 5 was filtered off and dried $(0.30 \mathrm{~g}, 68 \%)$.

Method 2. Semicarbazone $2(2.00 \mathrm{~g}, 7.3 \mathrm{mmol})$ was dissolved in a boiling solution of sodium hydroxide $(1 \mathrm{M}, 100 \mathrm{~mL})$. This mixture was boiled for $3 \mathrm{~h}$ and after cooling was acidified with acetic acid. The resulting compound $\mathbf{3}$ was immediately filtered off; the filtrate left to stand for two days and the resulting solid was filtered off, washed with water and dried affording the slightly yellow solid 5 (0.47 g, 32\%); mp (ethanol) 245-246 ${ }^{\circ} \mathrm{C}$. IR (KBr): $\widetilde{v} 3205(\mathrm{NH}), 1717$ $\mathrm{cm}^{-1}(\mathrm{CO}) .{ }^{1} \mathrm{H}$ NMR $\left(300 \mathrm{MHz}, \mathrm{DMSO}-d_{6}\right): \delta 3.56\left(2 \mathrm{H}, \mathrm{s}, \mathrm{CH}_{2}\right), 6.75\left(1 \mathrm{H}, \mathrm{d}, J=8 \mathrm{~Hz}, \mathrm{H}_{\text {arom }}\right)$, $7.42\left(1 \mathrm{H}, \mathrm{d}, J=8 \mathrm{~Hz}, \mathrm{H}_{\text {arom }}\right), 10.62(1 \mathrm{H}, \mathrm{s}, \mathrm{NH})$. Anal. calcd. for $\mathrm{C}_{8} \mathrm{H}_{5} \mathrm{Cl}_{2} \mathrm{NO}(202,04)$ : C, 47.56; H, 2.49; N, 6.93. Found: C, 47.74; H, 2.37; N, 6.95.

8,9-Dichloro-2,5-dihydro-3H-[1,2,4]triazino[5,6-b]indol-3-one (6). Triazine 3 (0.95 g, 4 mmol) was dissolved in acetic acid $(100 \mathrm{~mL})$. The mixture was boiled for one $\mathrm{h}$. The solid formed was filtered off, washed with water and dried yielding the yellow solid $6(0.79 \mathrm{~g}, 89 \%)$; mp $>360{ }^{\circ} \mathrm{C}$ (ethanol). IR (KBr): $\widetilde{v} 1649(\mathrm{CO}), 1596 \mathrm{~cm}^{-1}(\mathrm{NH}) .{ }^{1} \mathrm{H}$ NMR (300 MHz, DMSO-d $)$ ): $\delta 7.28(1 \mathrm{H}$, $\left.\mathrm{d}, J=9 \mathrm{~Hz}, \mathrm{H}_{\text {arom }}\right), 7.71\left(1 \mathrm{H}, \mathrm{d}, J=9 \mathrm{~Hz}, \mathrm{H}_{\text {arom }}\right), 12.19(1 \mathrm{H}, \mathrm{s}, \mathrm{NH}), 13.23(1 \mathrm{H}, \mathrm{s}, \mathrm{NH})$. Anal. calcd. for $\mathrm{C}_{9} \mathrm{H}_{4} \mathrm{Cl}_{2} \mathrm{~N}_{4} \mathrm{O}$ (255.06): C, 42.38; H, 1.58; N, 21.97. Found: C, 42.43; H, 1.49; N, 21.84.

6-(2,3-Dichlorophenyl)[1,2,4] triazine-3,5(2H,4H)-dione (8). Derivative 3 (0.15 g, $0.6 \mathrm{mmol})$ was dissolved in sodium hydroxide $(10 \%, 5 \mathrm{~mL})$ with heating. After cooling sodium nitrite (62 $\mathrm{mg}, 0.8 \mathrm{mmol}$ ) was added, and the mixture was cooled in an ice bath to $5{ }^{\circ} \mathrm{C}$. This solution was added dropwise to an ice cold mixture of hydrochloric acid $(3.5 \mathrm{~mL})$ and water $(3.5 \mathrm{~mL})$. The 
mixture was stirred for $15 \mathrm{~min}$ and hypophosphorous acid $(50 \%, 0.37 \mathrm{~mL})$ was added. The mixture was left at room temperature over night. The formed solid was filtered off, washed with water and dried affording the white solid 8 (133 mg, 93.7\%); mp 235-240 ${ }^{\circ} \mathrm{C}$ (ethanol). IR $(\mathrm{KBr}): \widetilde{v} 3432(\mathrm{NH}), 1746 \mathrm{~cm}^{-1}(\mathrm{CO}) ;{ }^{1} \mathrm{H}$ NMR (300 MHz, DMSO-d 6 ): $\delta 7.45$ (2H, m, $\mathrm{H}_{\text {arom }}$ ), $7.74\left(1 \mathrm{H}, \mathrm{m} \mathrm{H}_{\text {arom }}\right), 12.21(1 \mathrm{H}, \mathrm{s}, \mathrm{NH}), 12.58(1 \mathrm{H}, \mathrm{s}, \mathrm{NH})$. Anal. calcd. for $\mathrm{C}_{9} \mathrm{H}_{5} \mathrm{Cl}_{2} \mathrm{~N}_{3} \mathrm{O}_{2} \cdot \mathrm{H}_{2} \mathrm{O}$ (276.08): C, 39.16; H, 2.56; N, 15.22. Found: C, 39.68; H, 2.03; N, 14.92.

6-(2,3,6-Trichlorophenyl)[1,2,4]triazine-3,5(2H,4H)-dione (9). Triazine 3 (227 mg, $0.8 \mathrm{mmol})$ was dissolved sodium hydroxide $(10 \%, 5 \mathrm{~mL})$ with heating. After cooling sodium nitrite (64 mg, $0.9 \mathrm{mmol}$ ) was added, the resultant mixture was cooled in an ice bath to $5{ }^{\circ} \mathrm{C}$ and added dropwise to an ice cold mixture of hydrochloric acid $(2.5 \mathrm{~mL})$, water $(2.5 \mathrm{~mL})$ and toluene $(2.5$ $\mathrm{mL})$. After stirring for $15 \mathrm{~min}$ the resulting diazonium salt solution was carefully added to a solution of $\mathrm{Cu}_{2} \mathrm{Cl}_{2}(100 \mathrm{mg}, 0.5 \mathrm{mmol})$ in hydrochloric acid $(37 \%, 8 \mathrm{~mL})$ and water $(8 \mathrm{~mL})$. The mixture was stirred at room temperature overnight. The formed white solid was filtered off, washed with water and dried yielding the white solid 9 (199 mg, 81.9\%); mp 335-337 ${ }^{\circ} \mathrm{C}$ (ethanol). IR (KBr): $\widetilde{v} 3057\left(\mathrm{C}-\mathrm{H}_{\text {arom }}\right), 1699 \mathrm{~cm}^{-1}(\mathrm{CO}) ;{ }^{1} \mathrm{H}$ NMR (300 MHz, DMSO-d $): \delta 7.71$ $\left(1 \mathrm{H}, \mathrm{d}, J=7 \mathrm{~Hz}, \mathrm{H}_{\text {arom }}\right), 7.88\left(1 \mathrm{H}, \mathrm{d}, J=7 \mathrm{~Hz}, \mathrm{H}_{\text {arom }}\right), 12.61(1 \mathrm{H}, \mathrm{s}, \mathrm{NH}), 12.96(1 \mathrm{H}, \mathrm{s}, \mathrm{NH})$. Anal. calcd. for $\mathrm{C}_{9} \mathrm{H}_{4} \mathrm{Cl}_{3} \mathrm{~N}_{3} \mathrm{O}_{2}$ (292.51):C, 36.96; H, 1.38; N, 14.37. Found: C, 37.02; H, 1.68; N, 13.82 .

6-(6-Bromo-2,3-dichlorophenyl)[1,2,4]triazine-3,5(2H,4H)-dione (10). This compound was prepared analogously to the previous one employing a solution of $\mathrm{Cu}_{2} \mathrm{Br}_{2}(143 \mathrm{mg}, 0.5 \mathrm{mmol})$ in of hydrobromic acid $(48 \%, 5 \mathrm{~mL})$ and water $(5 \mathrm{~mL})$ affording the white solid 10 (243 $\mathrm{mg}, 86.8 \%)$; mp 355-357 ${ }^{\circ} \mathrm{C}$ (ethanol). IR (KBr): $\widetilde{v} 3244(\mathrm{NH}), 3055\left(\mathrm{C}-\mathrm{H}_{\text {arom}}\right), 1698 \mathrm{~cm}^{-1}(\mathrm{CO})$; ${ }^{1} \mathrm{H}$ NMR (300 MHz, DMSO- $\left.d_{6}\right): \delta 7.76\left(2 \mathrm{H}, \mathrm{m}, \mathrm{H}_{\text {arom }}\right), 12.49(1 \mathrm{H}, \mathrm{s}, \mathrm{NH}), 12.84(1 \mathrm{H}, \mathrm{s}, \mathrm{NH})$. Anal. calcd. for $\mathrm{C}_{9} \mathrm{H}_{4} \mathrm{BrCl}_{2} \mathrm{~N}_{3} \mathrm{O}_{2}$ (336.96): C, 32.08; H, 1.20; N, 12.47. Found: C, 31.86; H, 1.09; N, 12.33 .

6-(2,3-Dichloro-6-iodophenyl)[1,2,4]triazine-3,5(2H,4H)-dione (11). Triazine 3 (196 mg, 0.7 $\mathrm{mmol}$ ) was dissolved in $\mathrm{NaOH}(10 \%, 2 \mathrm{~mL})$, and sodium nitrite $(54 \mathrm{mg}, 0.8 \mathrm{mmol})$ was added. The mixture was cooled in an ice bath and slowly added to an ice cold mixture of hydrochloric acid $(2 \mathrm{~mL})$ and water $(5 \mathrm{~mL})$. The mixture was stirred for $15 \mathrm{~min}$. To the resulting diazonium salt solution was added a solution of potassium iodide $(130 \mathrm{mg}, 0.8 \mathrm{mmol})$ in water $(2 \mathrm{~mL})$. The next day the resulting solid was filtered off, washed with water and dried furnishing the pink solid 11 (251 mg, 91\%); mp above $360{ }^{\circ} \mathrm{C}$ (ethanol). IR (KBr): $\widetilde{v} 3049\left(\mathrm{C}-\mathrm{H}_{\text {arom }}\right), 1699 \mathrm{~cm}^{-1}$ (CO); ${ }^{1} \mathrm{H}$ NMR: (300 MHz, DMSO-d $): \delta 7,60\left(1 \mathrm{H}, \mathrm{d}, J=7 \mathrm{~Hz}, \mathrm{H}_{\text {arom }}\right), 8,00(1 \mathrm{H}, \mathrm{d}, J=7 \mathrm{~Hz}$, $\left.\mathrm{H}_{\text {arom }}\right), 12.60(1 \mathrm{H}, \mathrm{s}, \mathrm{NH}), 12.93(1 \mathrm{H}, \mathrm{s}, \mathrm{NH})$. Anal. calcd. for $\mathrm{C}_{9} \mathrm{H}_{4} \mathrm{Cl}_{2} \mathrm{IN}_{3} \mathrm{O}_{2}(383,96)$ : C, 28.15; H, 1.05; N, 10.93. Found: C, 28.51; H, 1.15; N, 11.13 .

6-(2,3-Dichloro-6-hydroxyphenyl)[1,2,4]triazine-3,5(2H,4H)-dione (12). Triazine 3 (150 mg, $0.6 \mathrm{mmol})$ was dissolved in $\mathrm{NaOH}(10 \%, 5 \mathrm{~mL})$ with heating. After cooling sodium nitrite $(60$ $\mathrm{mg}, 0.8 \mathrm{mmol}$ ) was added, the mixture was cooled in an ice bath to $5{ }^{\circ} \mathrm{C}$, it was added dropwise to the cold solution of sulfuric acid $(96 \%, 3.5 \mathrm{~mL})$ and water $(3.5 \mathrm{~mL})$, and stirring in an ice bath was continued for $15 \mathrm{~min}$. The mixture was filtered and boiled for $30 \mathrm{~min}$. The resulting solid was filtered off, washed with water and dried yielding the orange solid 12 (120 mg, 80\%); mp 
314-319 ${ }^{\circ} \mathrm{C}$ (ethanol). IR (KBr): $\widetilde{v} 3299(\mathrm{NH}), 3037(\mathrm{NH}), 1741 \mathrm{~cm}^{-1}$ (CO). Anal. calcd. for $\mathrm{C}_{9} \mathrm{H}_{5} \mathrm{Cl}_{2} \mathrm{~N}_{3} \mathrm{O}_{3}$ (274,06): C, 39.44; H, 1.84; N, 15.33. Found: C, 39.48; H, 1.84; N, 15.05.

Ethyl 2-cyano-2-[[3,4-dichloro-2-(3,5-dioxo-2,3,4,5-tetrahydro[1,2,4]triazin-6-yl)phenyl]hydrazono]ethanoylcarbamate (13). Triazine 3 (326 mg, $1.2 \mathrm{mmol}$ ) was dissolved in $\mathrm{KOH}$ $(10 \%, 4 \mathrm{~mL})$ with heating. After cooling sodium nitrite $(80 \mathrm{mg}, 1.2 \mathrm{mmol})$ was added, the mixture was cooled in an ice bath and was slowly added to the cold solution of hydrochloric acid $(4 \mathrm{~mL})$ and water $(10 \mathrm{~mL})$. Stirring was continued for $15 \mathrm{~min}$ and the resulting diazonium salt solution was slowly added to a solution kept at $5-10{ }^{\circ} \mathrm{C}$ that was prepared by dissolving ethyl cyanoacetylcarbamate $(170 \mathrm{mg}, 1.1 \mathrm{mmol})$ in water $(53 \mathrm{~mL})$ with heating and and subsequent cooling to room temperature followed by addition of sodium acetate $(4.00 \mathrm{~g}, 49 \mathrm{mmol})$. The combined mixture was left in the refrigerator for three days. The resulting solid was filtered off, washed with water, dried and gave the pink solid 13 (380 mg, $72 \%$ ); mp $195{ }^{\circ} \mathrm{C}$ (ethanol). IR $(\mathrm{KBr}): \widetilde{v} 2757(\mathrm{CN}), 1780(\mathrm{CO}), 1742 \mathrm{~cm}^{-1}(\mathrm{CO}) ;{ }^{1} \mathrm{H}$ NMR $\left(300 \mathrm{MHz}, \mathrm{DMSO}-d_{6}\right): \delta 1.30(3 \mathrm{H}$, t, $\left.\mathrm{CH}_{3}\right), 4.24\left(2 \mathrm{H}, \mathrm{q}, \mathrm{CH}_{2}\right), 7.88\left(1 \mathrm{H}, \mathrm{d}, J=7 \mathrm{~Hz}, \mathrm{H}_{\text {arom }}\right), 8.13\left(1 \mathrm{H}, \mathrm{d}, J=7 \mathrm{~Hz}, \mathrm{H}_{\text {arom }}\right), 10.75$ $(1 \mathrm{H}, \mathrm{s}, \mathrm{NH}), 11.50(1 \mathrm{H}, \mathrm{s}, \mathrm{NH}), 12.33(1 \mathrm{H}, \mathrm{s}, \mathrm{NH}), 12.75(1 \mathrm{H}, \mathrm{s}, \mathrm{NH})$. Anal. calcd. for $\mathrm{C}_{15} \mathrm{H}_{11} \mathrm{Cl}_{2} \mathrm{~N}_{7} \mathrm{O}_{5} \cdot \mathrm{H}_{2} \mathrm{O}$ (458.22): C, 39.32; H, 2.86; N, 21.40. Found: C, 38.99; H, 2.76; N; 21.33.

2-[3,4-Dichloro-2-(3,5-dioxo-2,3,4,5-tetrahydro[1,2,4]triazin-6-yl)phenyl]-3,5-dioxo-2,3,4,5tetrahydro[1,2,4]triazine-6-carbonitrile (14). A solution of hydrazone 4 (107 $\mathrm{mg}, 0.2 \mathrm{mmol})$ in pyridine $(5 \mathrm{~mL})$ was refluxed for $8 \mathrm{~h}$. After pyridine was distilled off the residue was dissolved in $\mathrm{Na}_{2} \mathrm{CO}_{3}(10 \%, 5 \mathrm{ml})$, the solution was filtered and acidified with hydrochloric acid. The resulting solid was filtered off, washed with water and dried affording the orange solid 14 (73

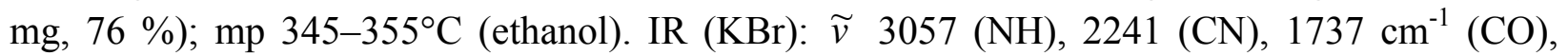
$1701(\mathrm{CO}) ;{ }^{1} \mathrm{H}$ NMR (300 MHz, DMSO-d $\left.)_{6}\right): \delta 7.70\left(1 \mathrm{H}, \mathrm{d}, J=7 \mathrm{~Hz}, \mathrm{H}_{\text {arom }}\right), 8.00(1 \mathrm{H}, \mathrm{d}, J=7$ $\left.\mathrm{Hz}, \mathrm{H}_{\text {arom }}\right), 12.33(1 \mathrm{H}, \mathrm{s}, \mathrm{NH}), 12.67(1 \mathrm{H}, \mathrm{s}, \mathrm{NH}), 13.10(1 \mathrm{H}, \mathrm{s}, \mathrm{NH})$. Anal. calcd. for $\mathrm{C}_{13} \mathrm{H}_{5} \mathrm{Cl}_{2} \mathrm{~N}_{7} \mathrm{O}_{4}$ (394.14): C, 39.62; H, 1.28; N, 24.88. Found: C, 39.98; H, 1.36; N, 24.68.

\section{Acknowledgments}

Financial support for this work by the Ministry of Education, Youth and Sport of Czech Republic, grant No 1531 000, and by the Grant Agency of the Czech Republic, grant No CEZ: J 14/98: N7 000000 8, is greatfully acknowledged.

\section{References}

1. Part 7 of the series "Analogs of biologically active compounds". For the previous paper see: Slouka, J.; Wiedermannova, I.; Frébortová, J.; Hajduch, M.; Strnad, M. Acta Univ. Palacki. Olomouc, Fac. Rerum Nat., Chimica 1999, 38, 65. Chem. Abstr. 2001, 134, 115499.

2. Fischer, J.; Gere, A. Pharmazie 2001, 56, 675. 
3. Baxter, M. G.; Elphick, A. R.; Miller, A. A.; Sawyer, D. A. Eur. Pat. Appl. 21, 121. Chem. Abstr. 1981 94. 208914.

4. Willmore, L. J. Expert Review of Neurotherapeuties 2001, 1, 33.

5. Nakada, V.; Lexner, J.; Kaspi, J. Eur. Pat. Appl. EP 1,927,873. Chem. Abstr. 2001, 135, 195578.

6. Hlaváč, J.; Slouka, J.; Hradil, P.; Lemr, K. J. Heterocycl. Chem. 2000, 37, 115.

7. Wiedermannová, I.; Slouka, J. J. Heterocycl. Chem. 2001, 38, 1465.

8. Bílek, P.; Slouka, J. J. Heterocycl. Chem. in press.

9. Mylari, B. L.; Miller, M. W.; Howes, H. L.; Figdor, S. K.; Lynch J. E.; Koch, R. C. J. Med. Chem. 1977, 20, 475.

10. Ryley, J. F.; Wilson, R. G.; Betts, M. J. Parasitology 1974, 68, 69.

11. Lyga, W.J. ACS Symposium Series No. 443, chapter 14: Synthesis and Chemistry of Agrochemicals II; ACS; Washington DC; 1991.

12. Baker, B. R.; Schaub, R. E.; Joseph, J. P.; McEvoy, F. J.; Williams, J. H. J. Org. Chem. 1952, 17, 149. 